University of Louisville

ThinkIR: The University of Louisville's Institutional Repository

Electronic Theses and Dissertations

1938

\title{
A study of the effect of rickets upon the cholesterol and fatty acid content of the brain.
}

Willa Holzheimer 1909-1996

University of Louisville

Follow this and additional works at: https://ir.library.louisville.edu/etd

Part of the Biochemistry, Biophysics, and Structural Biology Commons

\section{Recommended Citation}

Holzheimer, Willa 1909-1996, "A study of the effect of rickets upon the cholesterol and fatty acid content of the brain." (1938). Electronic Theses and Dissertations. Paper 1790.

https://doi.org/10.18297/etd/1790

This Master's Thesis is brought to you for free and open access by ThinkIR: The University of Louisville's Institutional Repository. It has been accepted for inclusion in Electronic Theses and Dissertations by an authorized administrator of ThinkIR: The University of Louisville's Institutional Repository. This title appears here courtesy of the author, who has retained all other copyrights. For more information, please contact thinkir@louisville.edu. 
UNIVERSITY OF LOUISVILLE

A STUDY OF THE EFFECT OF RICKETS UPON THF CHOLESTEROL AND FATSY ACID CONTENT OF THE BRAIN

\author{
A Dissertation \\ Submitted to the Faculty \\ Of the Graduate School of the University of Louisville \\ In Partial Fulfillment of the \\ Requirements for the Degree \\ Of Naster of Science \\ Department of Chemistry
}

By

Willa Holzheimer

Year

1938 
NAUE OF STUDENT:

TITLE OF THESIS: A STUDY OF THE BFEECT OF RICKETS UPON THE CHOLESTEROL AND FATTY ACID CONTENT OF THE BRAIN

TAIE OF DIRECTOR:

APHROVED BY A RTADING CONITIES CONPOSED OF THE FOLIONING:

REPRESENTATIVE OF THE DEFARTMENT OF TNGLISH

DATP: Lene/938 
AN ACKNOWLEDGRENT

The author of this thesis wishes to extend her grateful appreciation to Dr. H. E. Carswell for his direction and guidance in working out this problem; to Dr. A. W. Homberger for furnishing the experimental animals from his colony; and to Miss Hildred Schneiderhan for her assistance and suggestions regarding the care and feeding of the animals. 
TABIE OF CONPENTS

Page

I. Historical and Introduction I

II. Object of Experiment 5

III. Nethods $\quad 7$

IV. Experimental 12

V. Discussion 15

VI. Tables and Charts 20

VII. Summary 30

VIII. Notes 31

IX. Bibliography 33 
TISTORICAI ATD INTRODUCTION 
Cholesterol, the most important of animal sterols, was isolated from gall stones in 1785 by Fourcroy (1), when it was confounded with adipocre. Its true nature as a non-saponifiable fat-like body was discovered in 1815 by Chevreul (2), who named it "cholesterin" from the Greek, chole, bile; and steros, solid.

Evidence available at the present time seems to indicate definitely that the formula for cholesterol is the folloving:

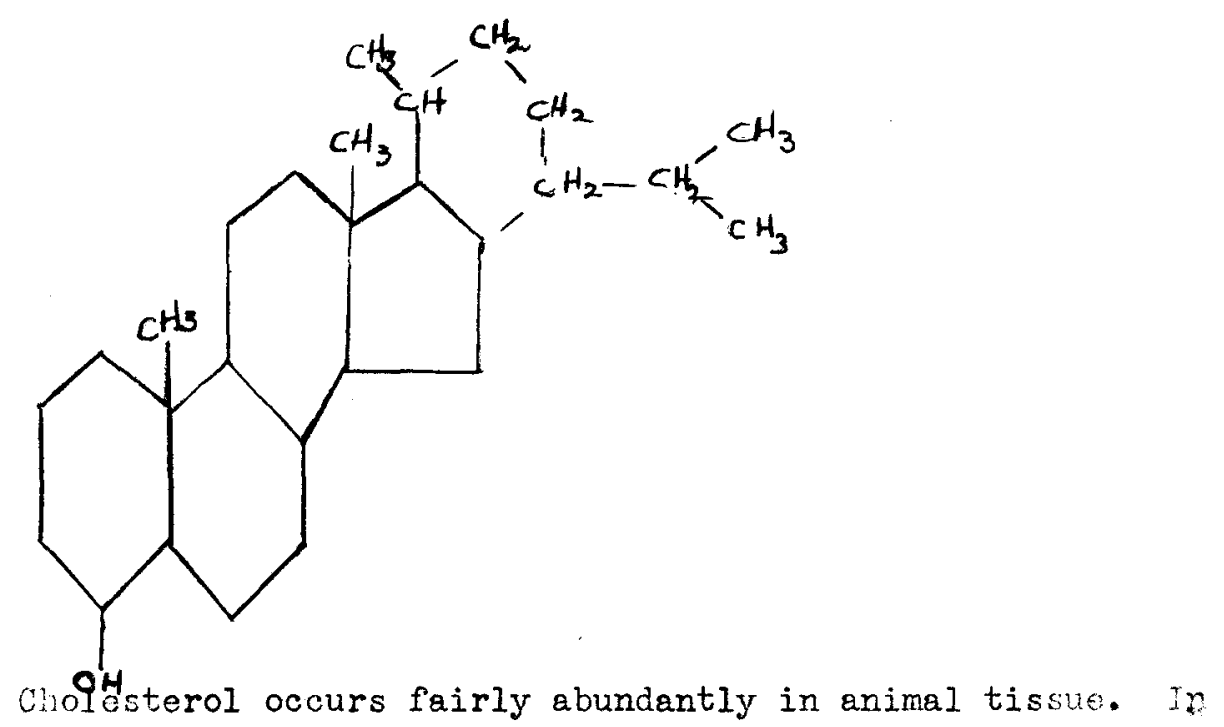

warm-blooded vertebrates (4) it is the only sterol found; but in lower animals and insects, somewhat variant forms are present. They all have the same formula an differ only in crystalline form and in the melting points of their dibromides and acetates. Cholesterol is also present in blood, bile, feces, wool fat, egg yolk, and milk. Its presence in all cells is in relatively fixed amounts characteristic for each tissue (5). It forms an important constituent of the 
medullary sheaths of nerve fibers, but it also occurs in the axis cylinder, since it is found in practically all cells (6). Cholesterol occurs in two forms, free and combined with fatty acids as esters, the esters being found in appreciable amounts only in blood plasma and in the suprarenal glands. Small amounts of the esters occur in the liver, kidney, heart, and probably in other organs and tissues; but the quantities are generally so small that there is always a question whether they are real constituents of the tissues or are due to the blood plasma present (7).

Except for the adrenal cortex, no organ contains such a large proportion of cholesterol as does the brain tissue. It is present to the extent of 0.5 per cent in five-month fetal brain, rapidly increases to 1.2 per cent in nurslings, and finally becomes stabilized at about 1.9 per cent in human adults ( 8$)$. It is claimed that 99 per cent of the cholesterol of the brain tissue (boy) is in the free state $(9)$.

It has been demonstrated experimentally that the lower plants can synthesize sterols from simple substances such as sugars, and in the case of the higher plants it has been shown that the formation of sterols can occur at any stage of development. Until a comparatively recent date it was generally believed that plants alone are capable of effecting the synthesis of the complicated sterol structures. Since cholesterol, the specific sterol of man and higher animals, does not occur in plants even in traces, it was assumed that the animal body assimilates phytosterol from the diet and transforms this substance into cholesterol (10). The balance of evidence seems to show that this assumption is not correct, and that the animal organism is capable of producing its own sterol. That cholesterol may be synthesized 
in the animal body is indicated by the fact that hens continue to lay eggs containing cholesterol when fed a cholesterol-free diet, and that the tissues of the rat contain the usual cholesterol content when fed on a diet containing no sterol. It has been suggested that the cholesterol may be synthesized in the body from the carbohydrate decomposition products (II); the site and mechanism, however, are unknown.

The cholesterol balance may be positive or negative, depending on the amount already present in the body, the amount in the food, and the ability to excrete sterol. Both synthesis and decomposition of cholesterol occur but the reactions involved in either case are unknown (12). Whether the brain acquires sterol from the blood stream or synthesizes its own sterol has not been investigated. Certainly the barrier between blood and spinal fluid shows little permeability for cholesterol (13).

Very little is actually known regarding the functions of cholesterol, but several very interesting theories have been presented which deserve some attention. It has been shown that the phospholipide and cholesterol content of tissues is highest in the brain, heart, and kidney, then in the muscle, and lowest in blood plasma. In muscle the content is hi hest in those muscles which are most used--heart, diaphragm, jaw, and pectoral muscles of flying birds. Although the part which they play in the life processes of these organs and tissues is not known, the relationship between amount of cholesterol and activity of the tissue is striking.

Cholesterol may assist in maintenance of proper water balance of cells. It is believed to stand in antagonistic relationship with phosphatides; and the ratio of cholesterol to fatty acids is thought to determine the amount of water held by a cell. Choles- 
terol also has both a protective function against hemolytic poisons and a detoxifying action for bacterial toxins. Whether these functions are exerted in the intact animal body remains purely speculative.

It seems highly probable that cholesterol is the parent substance from which the organism produces the important acis of the bile and the sex hormones (14), although this, of course, has not been established physiologically. Possibly, too, the antirachitic vitamin D comes from the same source or from a companion substance. The amount of cholesterol present in the body, however, appears out of proportion with that which would be adequate to meet these requirements, and the distribution of the substance is suggestive of other functions. From the abundance of cholesterol in the brain and nerves it has been suggested that the substance may be a protective agent for nervous matter. The biological function may be in part associated with the ability of cholesterol to precipitate hemolytic saponins, and the sterol may play a part in controlling cell permeability. None of these functions suggested, however, has been securely established and the problem awaits further investigation.

Although comparatively little is known definitely about the functional significance of cholesterol, variations from the nomal amount in blood have clinical or diapnostic value $(15,16,17,18)$. Organs of the body and tissues other than blood do not lend themselves as well to clinical investigation as does blood plasma; consequently, pathological variations in the liver, brain, and other tissues are not as well recognized as they are in blood. Some pathologic accumulations of cholesterol and phospholipides, however, have been identified (19).

It has beor lonow since 1824 (20) that cholesterol is one 
of the principal constituents of brain tissue, but its function in that organ remains unknown. Nomally, the cholesterol content of all cells of the body has been considered relatively fixed and characteristic for each iissue. Abnormal conditions in the body have brought about changes in the cholesterol content of many tissues but the variations in the brain, if any, have not been determined. The close relationship existing between cholesterol, ergosterol, and vitamin D suggested the possibility that rickets may influence the cholesterol balance in tissues. The brain of the white rat was selected as the tissue for study for several reasons:

1. The brain contains more free cholesterol than any other tissue except the adrenal cortex.

2. Vitamin $D$ has been found in small amounts in nervous tissues.

3. The cholesterol content of the brain of the white rat has not been determined directly. Ihe literature gives only the amount obtained by difference.

4. The white rat is used for the assay of vitamin D. Diets are available which will bring the animals to a desired state of depletion of vitanin $D$.

The objectives of this investigation were:

To determine the amount of cholesterol in the rat brain by direct methods, if possible.

To ascertain whether or not there is any variation from the normal in the cholesterol content of the brain in rickets. If there is such a variation, to determine whether or not the normal level is maintained in depleted and healed animals. To learn whether or not the fatty acids-cholesterol ratio 
is constant in the brain as Bloor has shown it to be in other tissue (21). 
MEPHODS 
METHODS

After the rats had been killed with chloroform they were weighed; and their weights, together with their overall lengths and tail lengths were recorded. The brains were then removed in the following way: the bones of the skull were removed from above--the meninges being left intact. Care was taken to preserve the flocculi which lay in bony pockets. The brain was severed fron the cord by a section at the level of the first cervical nerve--coinciding as a rule with the tip of the calamus as seen from the dorsal aspect. The brain was then raised from the floor of the cranium--the nerves being clipped close to the bases. The hypophysis was not included. Care was taken to obtain the olfactory bulbs entire. Thus prepared the brain was dropped into a snall previously weighed Erlenmeyer flask, and the flask was reweighed. In this manner the actual weight of the brain was obtained.

The determination of the amount of cholesterol in the brains was made by use of Imbden's Cholesterol Assay liethod (22), a modification of the method of Embden and Lawacreck. To each brain (approximately two grams of tissue) was added twenty cc. of $25 \%$ potassium hydroxide and the contents of the flask was allowed to saponify for two hours under reflux on a water bath. The mixture was then extracted six times by shaking for five minutes with fifty cc. portions of ether. Each fraction was washed with five cc. portions of water. The ether was distilled from the combined fraction, the residue dried at $60-80^{\circ} \mathrm{C}$. and dissolved in twenty cc. of chloroform. Two 5-ce. aliquot, were treated with two cc. of acetic 
anhydride and one-tenth cc. of sulphuric acid. Five cc. of a standard cholesterol solution (containing five mg. of cholesterol) was similarly treated with acetic anhydride and sulphuric acid. Both standard and unknown solutions were then put in the refrigerator for fifteen minutes, and then compared in a colorimeter.

The original article recomended washing the ether extracts with ten cc. portions of water, but it was found that emulsions often resulted because of the presence of soaps. The use of two five cc. portions averted this difficulty. Also the original article suggested setting the flasks in a dark closet for fifteen minutes, before comparing in the colorimeter. It was found, however, that puting the flasks in the refrigerator decreased the rate of reaction so that a bright reen color was obtained, which was compared in the colorimeter with much greater facility than was the pale yellow color formerly obtained by allowing the solution to stand overnight. The method outlined above made possible the determination of cholesterol in the individual rat brain rather than a calculated average of a group of six or seven.

$$
\text { Calculation: } \frac{\text { Reading of Standard }}{\text { Reading of Unknown }} \times 5 \times 4=\text { Mg. of choles- }
$$

terol per brain.

The residue containing the saponified, fats, from which cholesterol was extracted, was then used for determination of fatty acids by the method of Stoddard and Drury (23), as follows: the solution was made acid to thymol blue with $30 \%$ hydrochloric acid (faintly pink) and placed in cold water for ten minutes. The rixture was then centrifued and the solution completely separated from the fatty acids within five minutes. 
Filters were prepared beforehand in the following manner: a Gooch crucible of the smallest size (top $28 \mathrm{~mm}$. bottom and $18 \mathrm{~mm}$. in diameter) was set in a rubber washer which fit over the top of a small funnel. The stem of the funnel was passed through a rubber stopper which fit in a $500 \mathrm{cc}$. suction flask. A paper pulp emulsion was made by shaking a piece of soft filter paper, such as Achlieicher and Schull black ribbon $\$ 589$, in $300-400 \mathrm{cc}$. of distilled water. Ihis emulsion was vigorously shaken and immediately poured into a crucible while subjected to strong suction. This was repeated until a filter layer about $1 \mathrm{~mm}$. thick was produced. This layer was carefully tamped down with the end of a glass rod. Time was allowed for the larger masses of filter pulp fibers in the emulsion to settle out; then successive amounts of the thin upper suspension of isolated shreds were poured on. While strong suction was continued the filter was tamped occasionally until it was sufficiently dense to resist the suction. The crucible was removed from its rubber washer, dried in an air oven at $110^{\circ} \mathrm{C}$. for fifteen minutes and cooled. A row of the funnels which fit the crucible washers was set up. A crucible was placed in its washer in a funnel. With a test tube under the funnel, some of the fatty acid suspension was poured into the crucible. If the filtrate was not perfectly clear, it was returned to the crucible and refiltered. If filtration did not berin in a few minutes, the crucible and funnel were transferred to a filter flask, with a test tube under the funnel, and gentle suction started. After filtration had begun it was continued without suction. when the fatty acid suspension was filtered and the crucible drained, the precipitate was washed with four cc. of $5 \%$ sodium chloride, neutralized to phenolphthalein with not more than $.05 \mathrm{cc}$. of .02 normal sodium hydroxide. 
Three washings were usually required.

The crucible was then placed again in the suction flask, with a test tube (calibrated at 1 cc. intervals from $10-15$ cc.) under the funriel. The walls of the beaker were washed down with 5 cc. of alcohol, which was then heated to boiling and poured into tre crucible. Any fatty acid fragments on the walls of the crucible were quickly loosened with a glass rod. When the alcohol had nearly run out, moderate suction was applied. The beaker and crucible were washed out twice with three cc. portions of alcohol at the boiling point. Finally the outsides of the crucible and the funnel were washed in the same nanner.

After the addition of a few grains of sand, the filtrate was boiled for one minute. It was then cooled in a beaker, the volume of alcohol roted, and three drops of $0.3 \%$ thymol blue in $50 \%$ alcohol added. The solution was titrated with .02 normel sodium hydroxide to a pure blue color which remained practically unchanged with no yellow tinge while it was stirred for two minutes with a stopper in the mouth of the tube to avoid absorption of carbon dioxide. Ten cc. of alcohol was boiled down to the same volume as the boiled solution of fatty acids and was titrated as a blank. Calculation: A. represents the cc. of .02 normal alkali used to titrate the solution. B. represents the cc. of .02 nomal alkali used to titrate the blank. C. is an additional correction equivalent to $.005 \mathrm{cc}$. of .02 normal alkali, which must be subtracted from A. to correct for the effect upon the end point of each cc. of water added with the alkali. Hence, $A-C$ is $.995 A$. The calculation thus becomes: 
$.02(.99 \mathrm{~A}-3)$ equals the millimoles of fatty acid in the sample titratod. To transpose into milligrams of fatty acids, multiply millimoles by 277 , the average weight of the fatty acids. 
TIPERIMENTAL 
EXFETERTAL

The brains of thirty nomal males were removed in the prescribed manner and weighed. These brain weights were compared to the body weights to see what variation, if any, existed. The data are plotted in Figure 1.

After a reasonable deree of proficiency had been acquired in removing the brain, with its flocculi and olfactory bulbs intact, cholesterol determinations were made on groups of six and seven brains combined. Since this gave only a composite picture and told nothing about the individual brain, this crocedure was soon abandoned and analyses were made on separate brains only.

In order to determine the average amount of cholesterol in the brain of nornal rats, animals of different ages and weights (male and female) were taken from a colony in which all had had the same adequate diet. The ages of the animals in this experiment ranged from twenty-six days to one year, and their weights from thirty-six to three hundred and two grans. The results of this experiment are shown in Table 1.

The animals that were to be depleted of vitamin $D$ had been kept, since reaning, on a diet low in vitamin $D$. At the age of from twenty-eight to thirty-three days they were put on the Steenbock vitamin D-free diet $\$ 2065$. After about twenty-one days, the animals usually showed definite sins of becoming rachitic; for exmple, their eyes became inflamed and their noses raw and red. They seemed disinclined to nove about and developed an awkward crawling gait. A normal well balanced diet containing milk and greens was 
employed to "heal" the rachitic animals. Twenty-one days was usually sufficient time to bring about complete recovery, as evidenced by a disappesance of the above mentioned symptoms and the reappearance of the normal activity of healthy rats.

Eight rachitic rats were used in the second experiment. These animals were from forty-rine to fifty-one days of age, having been placed on the rachitogenic diet at twenty-eight days of age. Their weigits at the beginning of the experiment ranged from fiftythree to sixty-seven grams. At the expiration of the usual three weeks necessary to produce rickets, four of the animals (all males) were killed and cholesterol determinations made in the usual manner. The fatty acid content of each brain was also determined by the method of Stoddard and Drury described above. The remaining four rachitic rats (females) were put on a normal well balanced diet containing milk and green vegetables, and then killed at the end of twenty-one days. Cholesterol and fatty acid determinations were made and the results compared with those obtained on the four rachitic males. Results on all eight animals are shown in Table III. Experiment Three was made on eight normal, twenty-eight day old rats, weighing from thirty-seven to seventy grams. Four rats were placed on the rachitogenic diet and the remaining four on a normal diet. $\Lambda 11$ eight were killed at the end of twenty-one days and cholesterol and fatty acias detemined as previously. The results of these analyses are shown in Table IV.

The fourth experiment was performed on four groups of rats, whose weights ranged from forty-three to eighty-five grams. Each group contained four twenty-eight to thirty-three day old animals (three males and one female). Groups one and Two were 
placed on the normal diet and were used as controls. Groups Iwo and Four were placed on the rachitogenic diet. After twenty-one days, Groups Two and Three were killed, the brains removed, and the cholesterol determinations made. Group one (normal) was maintained on the normal diet and Group Four (rachitic) was also placed on the normal diet. I'wenty-one days later, both these groups were chloroformed and the cholesterol determinations made. In this way, the rachitic animals were compared with normal animals of. the same age, and the healed rats with normal rats also of the same afe. The results obtained from these analyses of the brains of the four groups are given in Table $V$. 
DISCUSSION 


\section{DISCUSSION}

In order to obtain significant data from comparative studies with rats, it is desirable to limit the variables to a minimum by. using animals of the same stock, age, weight and dietary experience.

Rickets is the result of inadequate nutrition in the young, growing animal; therefore, young animals have to be used in experiments which attempt to show any variations in chemical composition of the body in rickets. The question may be raised that, since the animals were young and growing, the composition of the different parts of their bodies might be in constant flux. This is a pertinent question and one which needs careful consideration, but it is believed that this variable is controlled in the selection of animals for experimentation which are not younger than twenty-eight days.

The findings of Koch and Koch (24) tends to support this contention. They divide the growth of the vervous system of the rat into four periods: the first period, which lasts until about birth, is characterized by cell division; the second period, from birth to about ten days, is characterized by development of fibers from the cells and their increase in size; the third period, from the age of ten days to twenty days, is characterized by the most rapid growth of all and by the beginning of medullation; and the fourth period is characterized by a great reduction in the rate of formation of all substances except cerebrosides.

Donaldson (25) shows an increase in brain weight during the first ten days of life to the extent of about $35.8 \%$ of the adult brain. The next ten days shows an increase in brain weight of $24.7 \%$ 
of the final brain weight; the next twenty days an increase of only $5.8 \%$ of the eventual weight; and the period from forty to one hundred days an increase amounting to $7 \%$ of the final weight. Both Koch and Donaldson thus agree that the rate of growth of the brain has decreased greatly by the time the animal is twenty days of age.

This fact is shom graphically in the distribution curve in Figure 1, in which brain weights are plotted against body weights in grams. This curve was compiled by calculation by Hatai (26) of the Nistar Institute from his observations of rats of different aces. In Table I are listed data on twenty-three nomal rats ranging from twenty-six days to one year of age. The brain weights increse gradually with an increase in body weights and ages. The cholesterol content also increases gredually. In Figure 2 are shown curves for milligrams of cholesterol plotted against ages in days compared with the curve compiled by Koch and Koch. The latter obtained their data by difference from chemical analyses of the other proximate principles of rat brains. The data obtained in this investigation tend to show that the nearest point of arreement is at one hundred twenty days. Fxclusive of that agreement, the results obtaired by direct analysis are shown to be higher than those obtained by Koch and Koch. Instead of a decline in amount of cholesterol as the animals grow older as koch observed, the few large animals studied showed a contirual increase of cholesterol with increased size or age. The average content of the brains in this experiment was about 30.83 milligrams, which is about $1.9 \%$ of the total brain weight.

It will be noted that among this group of normal animals 
are four twenty-six day old rats (having been weaned only a few days before) weighing from thirty-six to sixty-six grams. Although these were the youngest and the smallest animals used, their brain weights were found to approximate closely the weichts of nomel forty day old rats. The cholesterol content of the brains, however, was the lowest of any of the animals analyzed. It has been previously rentioned that the brain of the human nursling contains only $1.2 \%$ of cholesterol, the eventual arnount of $1.0 \%$ not being attained until adulthocd. Ferein may lie the explanation of the small amount of cholesterol found in the brains of the very young rats analyzed.

Analyses of the brains of sixteen rachitic rats show a marled decrease in cholesterol content. The average cholesterol content is 1. $5 \%$ of the brain weight. The results may be seen in Table II. Igure 3 shows the relation between cholesterol content and brain weight for both rachitic and normal animals.

Examination of the data in Table III shows the cholesterol content of the brains of four animals killed at the end of twentyone days on a rachitogenic diet to be definitely below the normal amount.

It is observed from Table IV that the nomal controls have the normal amount of cholesterol in their brains at the end of the experiment while the rachitic animals show a narked decrease in cholesterol contert. Although the tests on the animals in Experiment iwo were not made at the same time as those in Experiment ihree, the animals came from the same stock, were of about the same age, were placed on the same rachitogenic diet; and those that were healed in Experinent Two were on the same adequate diet ss the controls in Experiment Three. These results indicate that there is either a 
diminuition in the cholesterol of brains of the rachitic anim or that the cholesterol content remained practically fixed at the level attained at an age of twenty-eight days. This fact is brought out in the distribution curve in Figure 3. Bohle (26) found an increase in the sizes of the heads in one-third of his cases of infant rickets. He sumised that the increase in size was due to a hydrocephalus of the brain. Bohle's findings may be an explanation of the failure of the rachitic brain to show a loss in weight. The water content of the brains was not determined in these experiments, but it is a point which should be investigated at some future time.

The fourth experiment was an attempt to test four croups of animals under as near the same conditions as possible. The data are given in Table V. Groups one and Three (controls) show the nomel average amount of cholesterol for normal animals of their ages and weights. Group Two shows the lowered cholesterol content as found in rachitic animals of previous experiments. Analyses of the two animals in Group four which recovered from rickets showed an average cholesterol content of $1.89 \%$ which is very close to the previously established amount of $1.9 \%$. It should be noted from the weights given in rable IV that the rachitic group dic not gain weight as rapidly durinp; the period of depletion as those shown in Group ore, but the brairs did not show a marked variation in weight as can be seen by comparine Groups One and Two. The results are very similar to those obtained in Experiment Two. It is interesting to note that in Group Four, one aniral gained only four grems, two lost weicht, one of wich died, and animal Number Four remained at the same weight. Three weet: later (after being put on a nomal diet) animal Number Four had nore than doubled his ori final weight, while animal Number 
Three had increased in weight only about one-third; yet both animals had the same per cent of cholesterol in their brains.

The results of determinations of the amounts of fatty acids in the brains of rachitic and normal animals are shown in Tables VI and VII. Although there is a rather wide variation in the fatty acidcholesterol ratio for incividual brains, the ratio of the aver re amcunts shows a trend of gradual increase in fatty acids with an increase in cholesterol. This result is not unexpected since Bloor found the ratio of cholesterol to fatty acids to be a constant for other tissues.

In the case of the fatty acid content of rachitic rat brains, results were inconsistent as shown in Table VII. If the ratio of the average amount of fatty acid and cholesterol is computed, it is found to be very nearly identical with that obtained with nomal animals. The ratio for rachitic animals is 2.05 and that for normal animals is 1.95. 
TABLES AID CHARTS 
TABLE I.

YORIIL RINS

\begin{tabular}{|c|c|c|c|c|c|c|}
\hline No. & $\begin{array}{l}\text { see } \\
\text { in } \\
\text { Days }\end{array}$ & sex & $\begin{array}{c}\text { Body ei ht } \\
\text { in } \\
\text { Grams }\end{array}$ & $\begin{array}{c}\text { Brain feight } \\
\text { in } \\
\text { Grams }\end{array}$ & $\begin{array}{c}\text { Per Cent } \\
\text { of } \\
\text { Cholesterol }\end{array}$ & $\begin{array}{l}\text { illigms } \\
\text { of } \\
\text { Cholesterol }\end{array}$ \\
\hline 1 & 26 & 9 & 36.0 & 1.270 & 1.49 & 18.49 \\
\hline 2 & 26 & d' & 39.0 & 1.246 & 1.50 & 18.72 \\
\hline 3 & 27 & $q$ & 45.0 & 1.388 & 1.48 & 20.31 \\
\hline 4 & 26 & $\underline{\varphi}$ & 53.5 & 1.369 & 1.47 & 20.17 \\
\hline 5 & 30 & d & 54.2 & 1.377 & 1.39 & 19.34 \\
\hline 6 & 28 & 8 & 56.5 & 1.310 & 1.40 & 19.60 \\
\hline 7 & 26 & 0 & 66.5 & 1.401 & 1.45 & 19.05 \\
\hline 8 & 40 & $\pi$ & 72.0 & 1.387 & 1.84 & 25.92 \\
\hline 9 & 40 & 8 & 75.0 & 1.405 & 1.79 & 24.86 \\
\hline 10 & 40 & $a$ & 75.0 & 1.332 & 1.82 & 26.34 \\
\hline 11 & 65 & 5 & 91.0 & 1.395 & 1.70 & 26.02 \\
\hline 12 & 40 & o & 92.5 & 1.447 & 1.88 & 26.89 \\
\hline 13 & 67 & 8 & 98.0 & 1.383 & 1.90 & 26.31 \\
\hline 14 & 68 & or & 100.6 & 1.495 & 1.87 & 27.91 \\
\hline 15 & 71 & a & 107.0 & 1.398 & 1.80 & 25.18 \\
\hline 16 & 76 & 8 & 122.0 & 1.618 & 1.99 & 32.28 \\
\hline 17 & 78 & d & 128.0 & 1.541 & 1.94 & 30.00 \\
\hline 18 & 85 & $a$ & 141.5 & 1.608 & 1.96 & 31.42 \\
\hline 19 & 85 & $\partial$ & $1 \leq 2.0$ & 1.555 & 2.01 & 31.13 \\
\hline 20 & 86 & $0^{4}$ & 143.0 & 1.630 & 1.96 & 32.08 \\
\hline 21 & 98 & 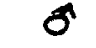 & 140.0 & 1.562 & 1.93 & 30.07 \\
\hline 22 & 109 & $q$ & 176.0 & 1.638 & 1.08 & 32.46 \\
\hline 23 & 109 & $\frac{7}{d}$ & 178.0 & 1.686 & 1.98 & 33.38 \\
\hline 24 & 115 & 8 & 184.0 & 1.723 & 1.79 & 30.95 \\
\hline 25 & 260 & $Q$ & 223.0 & 1.818 & 2.35 & 43.15 \\
\hline 26 & 185 & 0 & 242.0 & 1.919 & 2.03 & 39.02 \\
\hline 27 & $1 \mathrm{yr}$. & 0 & 283.0 & 2.090 & 1.99 & 41.60 \\
\hline 28 & $1 \mathrm{yr}$. & 高 & 302.0 & 1.093 & 2.29 & 45.65 \\
\hline
\end{tabular}


TA BLE TI.

BECIIIJC RES

\begin{tabular}{|c|c|c|c|c|c|c|}
\hline Ho. & Sex & $\begin{array}{l}\text { Age } \\
\text { in } \\
\text { Deys }\end{array}$ & $\begin{array}{l}\text { Body ieight } \\
\text { in } \\
\text { Grams }\end{array}$ & $\begin{array}{l}\text { Brain weight } \\
\text { in } \\
\text { Grams }\end{array}$ & $\begin{array}{c}\text { Per Cent } \\
\text { of } \\
\text { Cholesterol }\end{array}$ & $\begin{array}{c}\text { Pilligms. } \\
\text { of } \\
\text { Cholesterol }\end{array}$ \\
\hline 1 & 8 & 53 & 52.0 & 1.312 & 1.44 & 19.00 \\
\hline 2 & $a$ & 53 & 52.5 & 1.325 & 1.60 & 21.20 \\
\hline 3 & 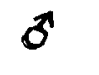 & 53 & 54.5 & 1.398 & 1.42 & 19.95 \\
\hline 4 & ס' & 53 & 58.5 & 1.379 & 1.53 & 22.20 \\
\hline 5 & $\sigma$ & 49 & 52.5 & 1.313 & 1.41 & 183.55 \\
\hline 6 & $\sigma$ & 49 & 53.0 & 1.242 & 1.55 & 19.26 \\
\hline 7 & む & 49 & 58.5 & 1.384 & 1.38 & 10.23 \\
\hline 8 & $\delta$ & 49 & 58.0 & 1.398 & 1.42 & 19.91 \\
\hline 9 & $d$ & 51 & 61.0 & 1.446 & 1.52 & 22.11 \\
\hline 10 & హ) & $5 I$ & 64.0 & 1.366 & 1.50 & 2.59 \\
\hline 11 & $\partial$ & 51 & 67.0 & 1.420 & 1.71 & 24.32 \\
\hline 12 & б & 56 & 71.0 & 1.393 & 2.45 & 20.20 \\
\hline 13 & 3 & 59 & 78.0 & 1.497 & 1.57 & 25.53 \\
\hline 14 & $\delta$ & 59 & 81.2 & 1.309 & 1.56 & 20.50 \\
\hline 15 & $\delta$ & 61 & 87.0 & 1.522 & 1.70 & 25.97 \\
\hline 16 & $\sigma$ & 59 & 95.5 & 1.595 & 1.41 & 22.48 \\
\hline
\end{tabular}


T.BLE III.

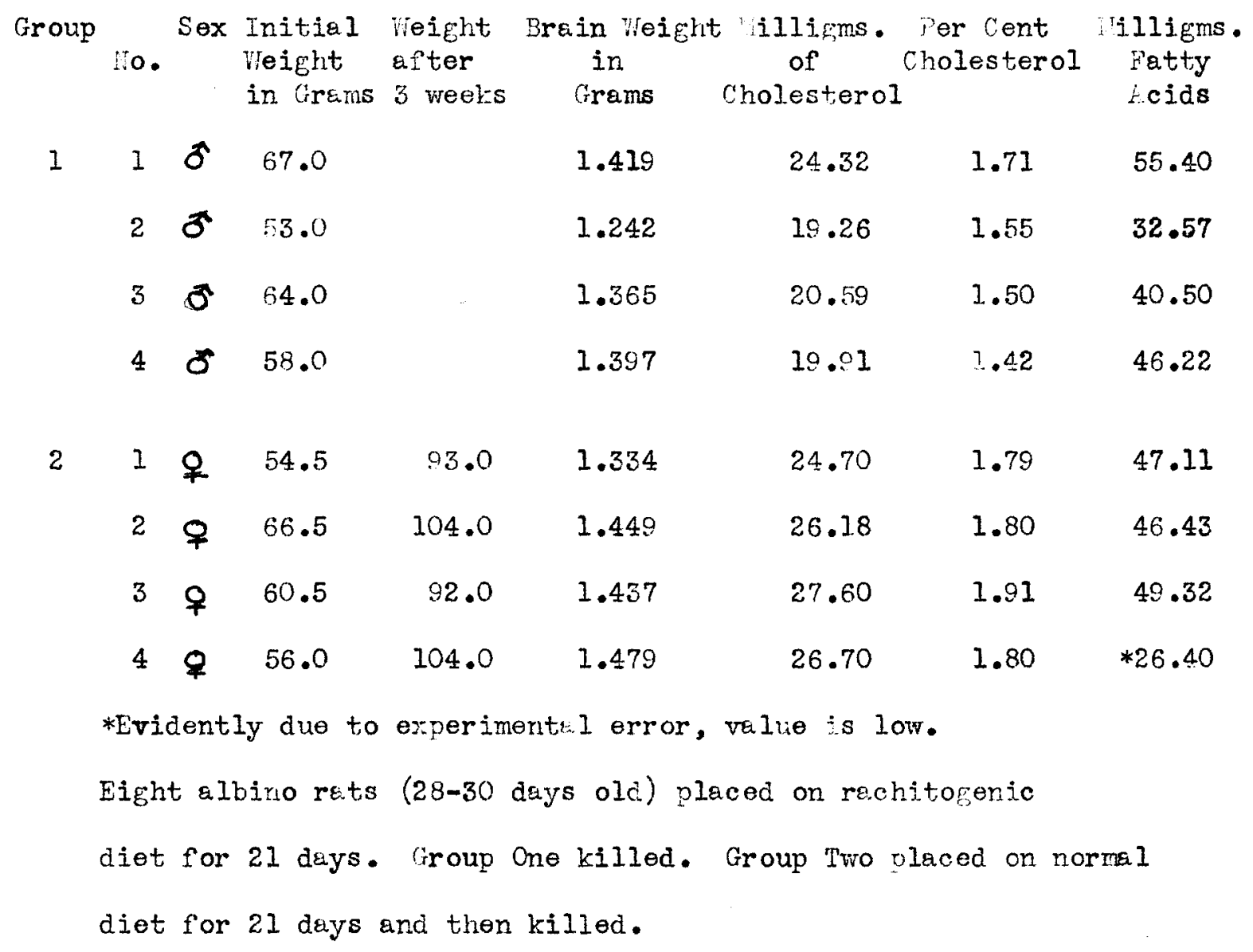




\section{T.BIE IV.}

\begin{tabular}{|c|c|c|c|c|c|c|c|c|}
\hline Group & No. & Sex & $\begin{array}{l}\text { Initial } \\
\text { Weight } \\
\text { in Grums }\end{array}$ & $\begin{array}{l}\text { Weight } \\
\text { after } \\
3 \text { weeks }\end{array}$ & $\begin{array}{c}\text { Brain Weight } \\
\text { in } \\
\text { Grams }\end{array}$ & $\begin{array}{l}\text { Hilligms. } \\
\text { of } \\
\text { Cholesterol }\end{array}$ & $\begin{array}{c}\text { Per Cent } \\
\text { of } \\
\text { Cholesterc }\end{array}$ & $\begin{array}{l}\text { illigms } \\
\text { of } \\
\text { IFatty Acids }\end{array}$ \\
\hline \multirow[t]{4}{*}{1} & 1 & 8 & 70 & 95.5 & 1.595 & 27.48 & 1.41 & 43.76 \\
\hline & 2 & る & 41 & 53.5 & 1.384 & 19.23 & 1.38 & 38.50 \\
\hline & 3 & $\delta$ & 48 & 61.0 & 1.446 & 22.11 & 1.52 & 39.98 \\
\hline & 4 & $\delta$ & 41 & 52.5 & 1.313 & 18.55 & 1.41 & 30.24 \\
\hline \multirow[t]{4}{*}{2} & 1 & 3 & 70 & 184.0 & 1.723 & 30.95 & 1.79 & 54.78 \\
\hline & 2 & $\sigma$ & 37 & 107.0 & 1.398 & 25.18 & 1.80 & 41.27 \\
\hline & 3 & 8 & 38 & 91.5 & 1.397 & 25.02 & 1.79 & 42.67 \\
\hline & 4 & 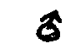 & 57 & 128.0 & 1.542 & 30.00 & 1.94 & 49.58 \\
\hline
\end{tabular}

Eight albino rats (28-31 days old). Group One placed on rachiticogenic diet for 21 d:ys. Group Two-normal controls. 
TABLE V

\begin{tabular}{|c|c|c|c|c|c|c|c|c|c|}
\hline Group & INo. & $\operatorname{sex}$ & $\begin{array}{l}\text { Initial } \\
\text { Weight } \\
\text { in Grams }\end{array}$ & $\begin{array}{l}\text { Weight } \\
\text { after } \\
3 \text { Weeks }\end{array}$ & $\begin{array}{l}\text { Weight } \\
\text { after } \\
6 \text { Weeks }\end{array}$ & $\begin{array}{l}\text { Brain } \\
\text { Weight } \\
\text { in Grams }\end{array}$ & $\begin{array}{c}\text { Milligms. } \\
\text { of } \\
\text { Cholesterol }\end{array}$ & $\begin{array}{c}\text { Per Cent } \\
\text { of } \\
\text { Cholesterol }\end{array}$ & $\begin{array}{l}\text { Milligms. } \\
\text { of } \\
\text { Fatty Acids }\end{array}$ \\
\hline 1 & $\begin{array}{l}1 \\
2 \\
3 \\
4\end{array}$ & $\begin{array}{l}\sigma \\
0 \\
0 \\
\delta \\
q\end{array}$ & $\begin{array}{l}55.0 \\
77.0 \\
85.0 \\
81.5\end{array}$ & $\begin{array}{r}98.0 \\
100.6 \\
141.5 \\
149.0\end{array}$ & & $\begin{array}{l}1.383 \\
1.495 \\
1.608 \\
1.562\end{array}$ & $\begin{array}{l}26.3 \\
28.0 \\
31.4 \\
30.1\end{array}$ & $\begin{array}{l}1.90 \\
1.87 \\
1.96 \\
1.93\end{array}$ & $\begin{array}{l}67.58 \\
59.01\end{array}$ \\
\hline 2 & $\begin{array}{l}1 \\
2 \\
3 \\
4\end{array}$ & $\begin{array}{l}3 \\
5 \\
0 \\
6\end{array}$ & $\begin{array}{l}50.5 \\
55.5 \\
63.5 \\
63.0\end{array}$ & $\begin{array}{l}71.0 \\
78.0 \\
81.2 \\
87.0\end{array}$ & & $\begin{array}{l}1.392 \\
1.497 \\
1.308 \\
1.522\end{array}$ & $\begin{array}{l}20.2 \\
23.5 \\
20.5 \\
26.0\end{array}$ & $\begin{array}{l}1.45 \\
1.57 \\
1.56 \\
1.70\end{array}$ & $\begin{array}{l}44.32 \\
31.85\end{array}$ \\
\hline 3 & $\begin{array}{l}1 \\
2 \\
3 \\
4\end{array}$ & $\begin{array}{l}3 \\
\delta \\
0 \\
\text { ơ } \\
\delta\end{array}$ & $\begin{array}{l}58.5 \\
67.0 \\
74.5 \\
77.0\end{array}$ & $\begin{array}{l}107.0 \\
112.0 \\
144.0 \\
150.0\end{array}$ & $\begin{array}{l}143.0 \\
142.0 \\
176.0 \\
178.0\end{array}$ & $\begin{array}{l}1.630 \\
1.555 \\
1.638 \\
1.686\end{array}$ & $\begin{array}{l}32.1 \\
31.1 \\
32.5 \\
33.4\end{array}$ & $\begin{array}{l}1.96 \\
2.01 \\
1.98 \\
1.98\end{array}$ & $\begin{array}{l}71.35 \\
66.48 \\
69.58 \\
79.11\end{array}$ \\
\hline 4 & $\begin{array}{l}1 \\
2 \\
3 \\
4\end{array}$ & $\begin{array}{l}9 \\
0 \\
5 \\
0 \\
0\end{array}$ & $\begin{array}{l}43.3 \\
65.0 \\
61.0 \\
71.5\end{array}$ & $\begin{array}{l}34.4 \\
\text { Di ed } \\
65.0 \\
71.5\end{array}$ & $\begin{array}{r}35.5^{*} \\
92.0 \\
149.0\end{array}$ & $\begin{array}{l}1.296 \\
1.407 \\
1.551\end{array}$ & $\begin{array}{l}21.5 \\
26.5 \\
29.4\end{array}$ & $\begin{array}{l}1.65 \\
1.88 \\
1.89\end{array}$ & \\
\hline
\end{tabular}

Sixteen albino rats (28-33 days old). Groups 1 and 3 controls. Groups 2 and 4 placed on rachitogenic diet for 21 days; group 2 killed; group 4 placed on normal diet for $2 l$ days and killed.

* Six days after being put on healing diet, animal no. 2 of group 4 being near death was chloroformed and brain cholesterol determined. 
T.BI.E VI.

NORML RHIS

\begin{tabular}{|c|c|c|c|c|c|}
\hline No. & Sex & $\begin{array}{c}\text { Final Weight } \\
\text { of Body } \\
\text { in Grams }\end{array}$ & $\begin{array}{c}\text { Brain Weight } \\
\text { in Grans }\end{array}$ & $\begin{array}{l}\text { illigrams } \\
\text { of } \\
\text { Cholesterol }\end{array}$ & $\begin{array}{l}\text { Filligrams } \\
\text { of } \\
\text { Fatty hcids }\end{array}$ \\
\hline 1 & $a$ & 56.5 & 1.310 & 19.05 & 37.11 \\
\hline 2 & 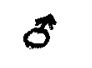 & 66.0 & 1.401 & 19.06 & 39.34 \\
\hline 3 & る & 72.5 & 1.387 & 24.86 & 45.09 \\
\hline 4 & a & 75.0 & 1.406 & 25.02 & 46.23 \\
\hline 5 & 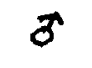 & 75.0 & 1.332 & 24.34 & 45.09 \\
\hline 6 & $\delta$ & 91.5 & 1.397 & 25.02 & 42.67 \\
\hline 7 & $\pi$ & 92.0 & 1.447 & 26.89 & 45.92 \\
\hline 8 & б & 98.0 & 1.383 & 26.31 & 67.58 \\
\hline 9 & $\pi$ & 107.0 & 1.398 & 25.18 & 41.27 \\
\hline 10 & $\sigma$ & 128.0 & 1.542 & 30.00 & 49.58 \\
\hline 11 & 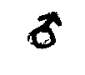 & 141.0 & 1.608 & 31.42 & 59.01 \\
\hline 12 & б & 142.0 & 1.555 & 31.13 & 66.48 \\
\hline 13 & 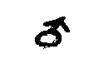 & 143.0 & 1.630 & 32.08 & 71.35 \\
\hline 14 & ठ & 176.0 & 1.638 & 32.46 & 69.58 \\
\hline 15 & $\delta$ & 178.0 & 1.686 & 33.38 & 79.11 \\
\hline $\begin{array}{l}16 \\
\text { Ave }\end{array}$ & $\delta^{\pi}$ & 184.0 & 1.723 & $\begin{array}{l}30.95 \\
21.40\end{array}$ & $\begin{array}{l}54.78 \\
53.76\end{array}$ \\
\hline
\end{tabular}




\section{TEBLE VII.}

RECHITIC RHTS

\begin{tabular}{|c|c|c|c|c|c|}
\hline No. & Sex & $\begin{array}{c}\text { Final Body } \\
\text { Weight } \\
\text { in Grams }\end{array}$ & $\begin{array}{c}\text { Brain Weight } \\
\text { in Grams }\end{array}$ & $\begin{array}{c}\text { Milligrams } \\
\text { of } \\
\text { Cholesterol }\end{array}$ & $\begin{array}{c}\text { Milligrams } \\
\text { of } \\
\text { Fatty icids }\end{array}$ \\
\hline 1 & $\sigma$ & 52.0 & 1.512 & 19.00 & 46.59 \\
\hline 2 & $\sigma$ & 52.5 & 1.313 & 18.55 & 30.24 \\
\hline 3 & $\sigma^{\pi}$ & 52.5 & 1.325 & 21.20 & 44.73 \\
\hline 4 & $\pi$ & 53.0 & 1.242 & 19.26 & 32.57 \\
\hline 5 & $\sigma$ & 53.5 & 1.384 & 19.23 & 38.50 \\
\hline 6 & 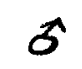 & 54.5 & 1.398 & 19.95 & 52.42 \\
\hline 7 & $\hat{\sigma}$ & 58.0 & 1.397 & 19.01 & 46.22 \\
\hline 8 & $a$ & 58.5 & 1.379 & 22.20 & 49.18 \\
\hline 9 & 8 & 61.0 & 1.446 & 22.11 & 39.88 \\
\hline 10 & $\delta$ & 64.0 & 1.365 & 20.59 & 40.50 \\
\hline 11 & 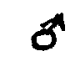 & 67.0 & 1.419 & 24.32 & 55.40 \\
\hline 12 & $a$ & 71.0 & 1.593 & 20.20 & 44.32 \\
\hline 13 & 우 & 31.2 & 1.309 & 20.50 & 31.85 \\
\hline $\begin{array}{l}14 \\
\text { A ver }\end{array}$ & $\theta$ & 95.5 & 1.595 & $\begin{array}{l}22.48 \\
20.67\end{array}$ & $\begin{array}{l}43.76 \\
42.52\end{array}$ \\
\hline
\end{tabular}




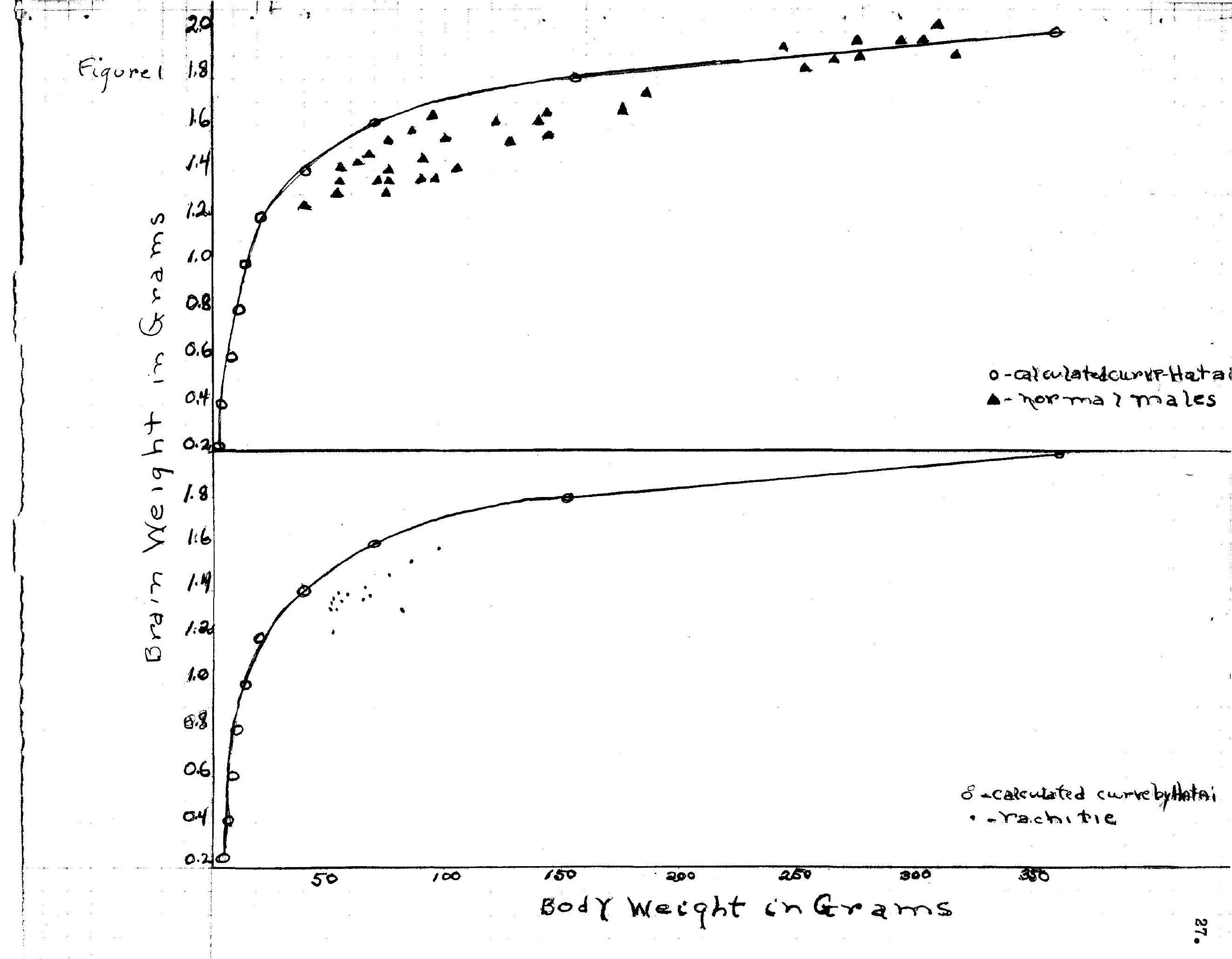




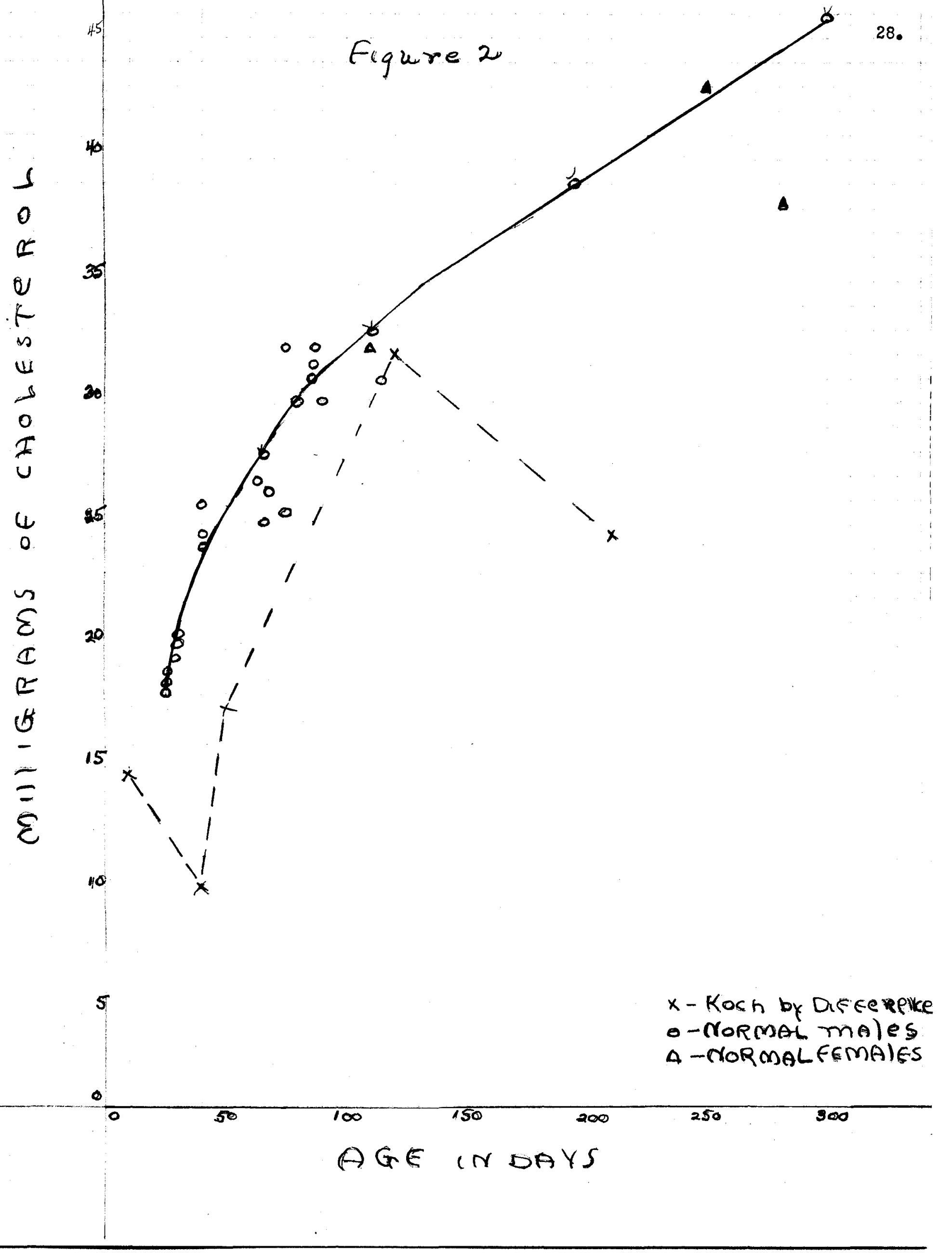




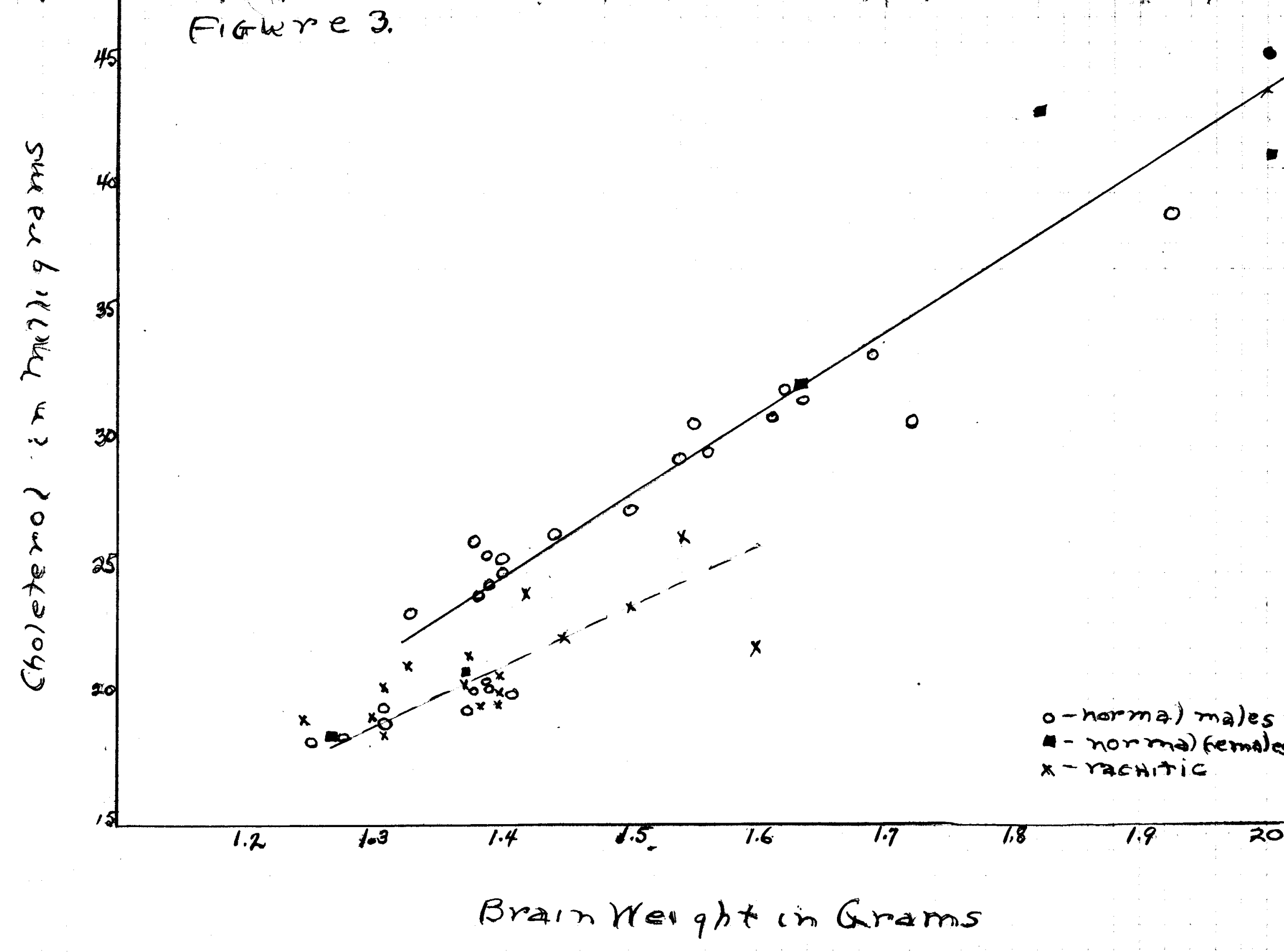


SUMPIARY

1. Cholesterol was determined in the brain of the Albino rat by a direct method.

2. The total amount of cholesterol was found to be higher than that determined by difference as previously reported in the literature. There was no indication that the amount decreases in animals older than one hundred twenty days. 3. The cholesterol content of the brain was found to increase with the increase in brain weight in both normal and rachitic animals, $\therefore$ but the increase in the rachitic animals was at a lower level and a slightly lower rate.

4. The average brain weight of rachitic animals was the same as that for normal animals of the same age. The average percentage of cholesterol, however, was 1.5 for rachitic animals and 1.9 for normal animals. 5. It is believed that rickets inhibits the metabolism of cholesterol. The lower cholesterol valves found in rachitic animals seems to be due to a diminished rate of deposition of cholesterol in the brain rather than to a direct loss of cholesterol. 6. Feedine an adequate diet for twenty-one days to animals with rickets restored the cholesterol and fatty acid content of the brain to about normal.

7. Fatty acids in the brain showed a tendency to vary with the amount of brain cholesterol in both rachitic and normal animals. 
NOTES AND BIBLIOGRAFHY 
(1) Nathew, A. P., 1920. Physiological Chemistry. New York: William rood and co. p.80.

(2) Chevreul, ..., Ann. Chim. 95, 5 (1815).

(3) Fieser, L. F., 1936. Chemistry of Natural Froducts Related to Phenanthrene. New York: Willian wood and Co. p.III.

(4) Harrow, B., and C. P. Sherwin, 1935. A Textbook of Biochemistry. Philadelphia and Londoñ W. B. Saunders. P.140.

(5) Harrow, B., and C. P. Sherwin, 1935. A Textbook of Biochemistry. Philadelphia and London: W. $_{\text {. }}$. Saunders.

(6) Van Slyke, D. D., and John F. Peters, 1931. Quantitative Clinical Chemistry. Baltimore: The Williams and Wilkins Co. p.837.

(7) Harrow, B., and C. P. Sherwin, 1935. A Textbook of Biochemistry. Philadelphia and London: W. B. Saunders. p.582.

(8) Fage, I. F., and F. Nenschick, Biochem. Z. 231, 448 (1931).

(9) Bills, C. D., "hysiology of the Sterols, Including Vitamin D." Fhysiol. Rev. 15, I (1935).

(10) Hawk, F. B., and Olaf Bergeim, 1931. Practical Physiological Chemistry. Philadelphia: F. Blakiston's Sons and Co.

(11) Page, I. H., and W. Henschick, J. Biol. Chem. 97, 359 (1932).

(12) Harrow, B., and C. P. Shermim, 1935. A Textbook of Biochemistry. Philedelphia and London: $\%$. B. Saunders

(13) Page, I. H., and W. kenschick, J. Biol. Chem. 97, 359 (1932).

(14) Fieser, L. F., 1936. Chemistry of Natural F'roducts Related to Phenanthrene. New York: Nilliam Wood and Co. p.122. 
(15) Lciee, J. W., Guert. Jour. Hed., Oxford. 1913-14, VI, 221.

(16) Chauffard, H., G. Larouche, and H. Grigkut, hrch. of Obstet. et de Gyn. Paris. 1912, XVII, 401.

(17) Fischer, Virochoro's Archiv. of Path., hnat. u. Mysiol. Berlin. 1903, CLXXI,218.

(18) Lyers, V.C., Jo.r. Iab. and Clin. Ied., St. Louis, 1919-20. V. 776 .

(19) Bloor, \%. R., J. Biol. Chem. 16, 517 (1914).

(20) Van Slyke, D. D., and john P. Jeters 1931. Quantitative Clinical Chemistry. Fultimore: The filliams and Wilkins Co. $\mathrm{p} .837$.

(21) Dloor, T. R. "Wistribution of Unsaturated Fatty hoids in Tissues." J. Biol. Chem. 66, 443 (1935).

(22) Lmbden, $G$. "L Iodification of the lethod of Fmbden and "sacrack." "agoya J. Hed. Sci. s, 135-37 (1935).

(23) Stoddard, J. I., and P. E. Drury "I. Titration liethod for Blood Fat." J. Biol. Chem. 84, 741 (1920).

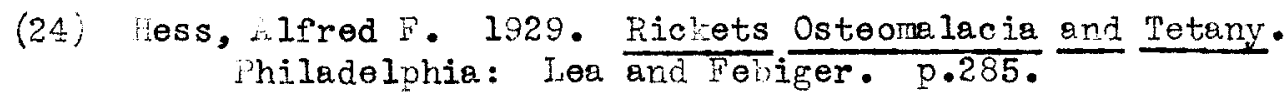

(25) Donaldson, Genry H. 1915. Philadelphia. p.183.

(26) Donaldson, Ilenry H. 1015. Philadelphia. n.90.. 
Bills, F. E., "hysiolory of the Sterols, Including Vitamin D." Fhysiol. Rev. 15, 1 (1935).

Bloor, W. K., "Determination of Cholesterol in Blood." J. Biol. Chern. 24, 227-3I (1926).

3loor, W. R., and Pelkan, J. Biol. Chem. 52 (1922).

Burchard, "Inaugural Dissertation." Rostock. 1889. Chem. Zentr. I, 25 (1890).

CampbeIl, John H., "Cholesterol in Health and Disease." quart. J. Nied. 18, $393(1924-25)$.

Channon, I. J., "Cholesterol Synthesis in the Animal Body." Biochem. J. 19, 424 (1924).

Chauffard, A., G. Iarouche, and H. Grigaut, Arch. of Obstet. et de Gyn. Paris. 1912, XVII, 401.

Chevreul, H., Ann. Chim. 95, 5 (1815).

Cook, R. P., "Fat Feeding and Cholesterol Absorption." Biochem. J. 31, 410-15 (1937).

Dam and Stamp, Biochem Z. 278, 342 (1935).

Donaldson, Henry H., 1915. The Rat. Philadelphia

Embden, G., "A lodification of the liethod of Imbden and Lawaczeck." Nagoya J. Ked. Sci. 8, 135-37 (1935).

Fex, John, Biochem. Zeit. 104, 82 (1920).

Fieser, L. F., 1936. Chemistry of Natural Products Related to Phenanthrene. New York: William Wood and Co.

Fischer, Virchoro's Archiv. of Path., Anat. u. Physiol. Berlin. 1903, CLXisI, 218.

Gardner, J. A., and F. Fox, "A Critical Study of the riethods of Estimation of Cholesterol and Its Esters in Tissues." Biochem. J. 18, 1058 (1921).

Gortner, R. A., 1929. Outlines of Biochemistry. London and New York: John Wiley and Sons Inc.

Harrow, B., and C. P. Sherwin 1935. A Pextbook of Biochemistry. Philadelphia and London:. $\bar{B}$. Saunders. 
Hawk, P. B., and Olaf Bergeim 1931. Fractical Physiological Chemistry. Philadelphia: P. Blakiston's Sons \& Co.

Koch, "i., and L. Koch, "The Chemical Differentiation of The Brain of the Albino Rat Euring Growth." J. Biol. Chem. 15, 423-448 (1913).

Iight, A. E., P. K. Smith, and A. A. Smith, "Total Lipides in Rat Tissues Under Restricted Salt Diet." J. Biol. Chem. 107, 689 (1934).

Iing, Schmorl, "Determination of Cholesterol in Small Amounts of Blood." J. Biol. Chem. 76, 36I (1928).

Long, A. "The Iipide Contents of Organs of Young Rats." $z$. Physiol. Chem. 246, 219-23 (1937).

Wathew, A. F. 1920. Physiological Chemistry. New York: villiam wood and Co.

kcNee, J. W., wuart. Jour. Hed., Oxford, 1913-14, VII, 221.

Myers, V. C., Jour. Lab. and Clin. Med., St. Louis, 1919-20, V. 776 .

Page, I. H., and W. Menschick, Biochem. Z. 231 448 (1931).

Randles, F. S., and Arthur Inudson, "Studies in Cholesterol." J. Biol. Chem. 86, 529 (1925).

Schoenheimer, R., and H. Dam, Sci. 74, 579.

Sinclair, R. G., J. Biol. Chem. 95, 393 (1932).

Sterneberg, R., Acta. Led. Scund. 71, I (1929).

Stoddard, J. L., and P. E. Drury, "A Titration lethod for Blood Fat." J. Biol. Chem., 84, 741 (1929).

Trumper, hax and Abraham Cantarow, 1932. Biochemistry in Internal Medicine. Philadelphia A. B. Saunders 